\title{
POVERTY ALLEVIATION BASED ON PARTICIPANT NEEDS AND LOCAL POTENCY: THE CASE OF PALEMBANG CITY AND OGAN KOMERING ILIR REGENCY
}

\author{
PENGENTASAN KEMISKINAN BERBASIS KEBUTUHAN \\ PARTISIPAN DAN POTENSI LOKAL: STUDI KASUS KOTA \\ PALEMBANG DAN KABUPATEN OGAN KOMERING ILIR
}

\author{
Dian Novriadhy ${ }^{1}$ dan Niken P.N. Rahayu ${ }^{2}$ \\ ${ }^{1,2}$ Badan Penelitian dan Pengembangan Daerah Provinsi Sumatera Selatan \\ Jln. Demang Lebar Daun No. 4864 Palembang, Indonesia \\ Email: dian.novriadhy@gmail.com
}

Naskah Masuk: :18-4-2019

Naskah Diterima: 19-11-2019

Naskah Disetujui: 19 -12-2019

\begin{abstract}
The research aimed to test the 2015 Integrated Data Base (IDB) reliability as a source in selecting poverty alleviation program's target and to develop community's empowerment model. The research conducted in 12 Kelurahan in Palembang City and 2 villages in Ogan-Komering-Ilir Regency from February 2017 to November 2018. Two-hundred-and-fifty-six participants were systematically selected from the 2015 IDB list. The data collected through FGD, interviews and participatory observation. The data analyzed and interpreted based on the input-processoutput approach. The research used three stages i.e. problem formulation, system's components identification, and empowerment model development. The research showed the use of the 2015 IDB resulted in $44.53 \%$ right-on-target within range 14.29 to $73.68 \%$ per kelurahan/village. The replacement of the targeted participant tended not in the 2015 IDB list. The unfamiliarity of Head of RT to the 2015 IDB suspected as the cause. The replacement was caused by: had moved to another location (91.55\%), already work (4.22\%), impaired health (3.52\%) and died (.7\%). The participant with different education level had an equal chance to accept empowerment program. The influence of the community's leader was an important factor in the empowerment program. The reliability of the 2015 IDB depended on the ability of program manager in diminishing of identity politics at the location. To increase the responsiveness, the community's assets also need to be developed alongside individual assets. The empowerment program is indeed an iterative process rather than linear, the program manager should aware of the constant changing of the participant needs.
\end{abstract}

Keywords: community empowerment model, poverty alleviation, the 2015 Integrated Data Base

\section{ABSTRAK}

Penelitian ini bertujuan untuk menguji keandalan Basis Data Terpadu (BDT) 2015 sebagai sumber dalam memilih target program pengentasan kemiskinan dan untuk mengembangkan model pemberdayaan masyarakat. Penelitian dilakukan di 12 Kelurahan di Kota Palembang dan 2 desa di Kabupaten Ogan-Komering-Ilir dari Februari 2017 hingga November 2018. Dua ratus lima puluh enam peserta dipilih secara sistematis dari daftar BDT 2015. Data dikumpulkan melalui FGD, wawancara dan observasi partisipatif. Data dianalisis dan ditafsirkan berdasarkan pendekatan input-proses-output. Penelitian ini menggunakan tiga tahap yaitu perumusan masalah, identifikasi komponen sistem, dan pengembangan model pemberdayaan. Penelitian menunjukkan penggunaan BDT 2015 menghasilkan ketepatsasaran 44,53\% ketepatsasaran dalam kisaran 14,29 hingga 73,68\% per kelurahan/desa. Penggantian peserta yang ditargetkan cenderung tidak ada dalam daftar BDT 2015. Ketidaktahuan Kepala RT terhadap BDT 2015 diduga sebagai penyebabnya. Penggantian tersebut disebabkan oleh: telah pindah ke lokasi lain (91,55\%), sudah bekerja (4,22\%), gangguan kesehatan (3,52\%) dan meninggal (0,7\%). Peserta dengan tingkat pendidikan yang berbeda memiliki kesempatan yang sama untuk menerima program pemberdayaan. Pengaruh pemimpin masyarakat merupakan faktor penting dalam program pemberdayaan. Keandalan BDT 2015 bergantung pada kemampuan manajer program dalam mengurangi politik identitas di lokasi. Untuk meningkatkan daya tanggap, aset masyarakat juga perlu dikembangkan bersamaan dengan aset individu. Program pemberdayaan memang merupakan proses berulang daripada linier, manajer program harus menyadari perubahan konstan dari kebutuhan peserta.

Kata kunci: Basis Data Terpadu 2015, model pemberdayaan masyarakat, pengentasan kemiskinan 


\section{INTRODUCTION}

Poverty is a multidimensional and complex problem that needs a systematic approach to solve it ( $\mathrm{Liu}, \mathrm{Yu}$, \& Wang, 2015). Understanding the local context of poverty is very crucial because characteristic of poverty are different for every place (Haughton \& Khandker, 2009). In an urban setting which a household typically has limited assets, optimizing labor resource become fundamental to overcome the threat of poverty (Costa, Machado, \& Amaral, 2017) while in rural setting improvement on an agricultural market become one of main option in poverty alleviation (Mellor \& Malik, 2017). Success in poverty alleviation has known correlated with the accuracy of target groups selection supported with qualified public administration (Fiszbein, Kanbur, \& Yemtsov, 2014).

Indonesia's strategies on Poverty Alleviation is carried out through four approaches: 1) improvement of social protection programs; 2) increasing accesses of the poor to basic services; 3) the poor group's empowerment; and 4) creating inclusive development (TNP2K, n.d.). Alignment of various activities intended to accelerate poverty reduction - which involve cross-stakeholders and across sectors - is a duty of the National Team for the Acceleration of Poverty Alleviation (NTAPA). One of the NT-APA mandates is to improve the accuracy of programs target based on the household and region. For this reason, NT-APA has developed an electronic data system that contained names and addresses, Population Identification Number (PIN), and social and economic information of households or individuals that more popularly called as the Integrated Data Base (IDB) (Sekretariat TNP2K \& TNP2K, 2012). The use of the IDB in the poverty alleviation is an order of Law Number 13 of 2011 so that all government organizations that deal with poverty reduction must refer to the data.

NT-APA officially designated the 2015 IDB as the first IDB that is used as a reference for poverty alleviation programs and according to the mandate of legislation must be updated at least every two years. Unfortunately, the IDB usage for poverty alleviation has two limitations. First, the IDB verification is carried out in multilevel (from the Village/Kelurahan level to the ministry level) making the latest updated data could not be used immediately following year. Second, based on Minister of Home Affairs Regulation Number 32 of 2011 the addressee of social support must submit written proposal to the regional head which must then be verified in the budget planning document which approved at least a budgetary year before. These limitations gave difficulties to implement poverty alleviation programs that targeting specific persons (except for the programs that implement Bantuan Langsung (directly give) 
that also became authors' reasons to use the 2015 IDB in this research aside from the 2017 IDB version also was not published at the time.

There are two issues concerning the 2015 IDB utilization: 1) at the level of local government organizations. Empirically, several poverty alleviation programs are not planned based on the 2015 IDB showing the lack of knowledge of government official about the existence of the 2015 IDB; and 2) the reliability of the 2015 IDB usage in the targeting of individuals/households to include in community empowerment activity from the beginning of the activity has not been widely evaluated (Bah, Nazara, \& Satriawan, 2015). Some research had evaluated the effectiveness of IDB usage (Sitepu, 2015; Vinda, 2017) while others had evaluate the accuracy of the IDB (Sudibyo, 2019).

Responding to these problems, the study aimed 1) to test the reliability of the 2015 IDB as a source of data in selecting targets participants and to test the accuracy level of target participants included in the community empowerment program and 2) to develop community empowerment model based on the target participants needs and the availability of local resources.

\section{METHOD}

The research was conducted from February 2017 to November 2018 with a systematic approach in three stages: 1) problem formulation, 2) system's components identification, and 3) empowerment model development. The data collected through Focus Group Discussion (FGD), interviews and observation. The study population was all households in the selected location that were registered in the 2015 IDB while the samples were purposively selected from the 2015 IDB list with the following criteria: a) woman, b) did not work/part-time worker in 2015 and c) member of first decile group (considered as the poorest). The final research participants were 256 people from 12 Kelurahan in Palembang City and 2 Villages in the Ogan Komering Ilir Regency.

Process selection of the research location (step 1) and the participants (step 2) were shown in Figure 1. The authors selected the Village/Kelurahan that most populated by "individuals who do not work according to age groups" as the research location. The author surveyed the available local resources and discussed the result to respective local stakeholders to determine what kind of community empowerment activities should be done. The local potential in this research is defined as the most type of small and medium-sized business/industrial activity carried out in the village/kelurahan of the research location.

Participants were selected in the following way: 
1. Selecting the prospective participant

from the targeted household (decile 1)

listed in the $2015 \mathrm{BDT}$;

Step 1:

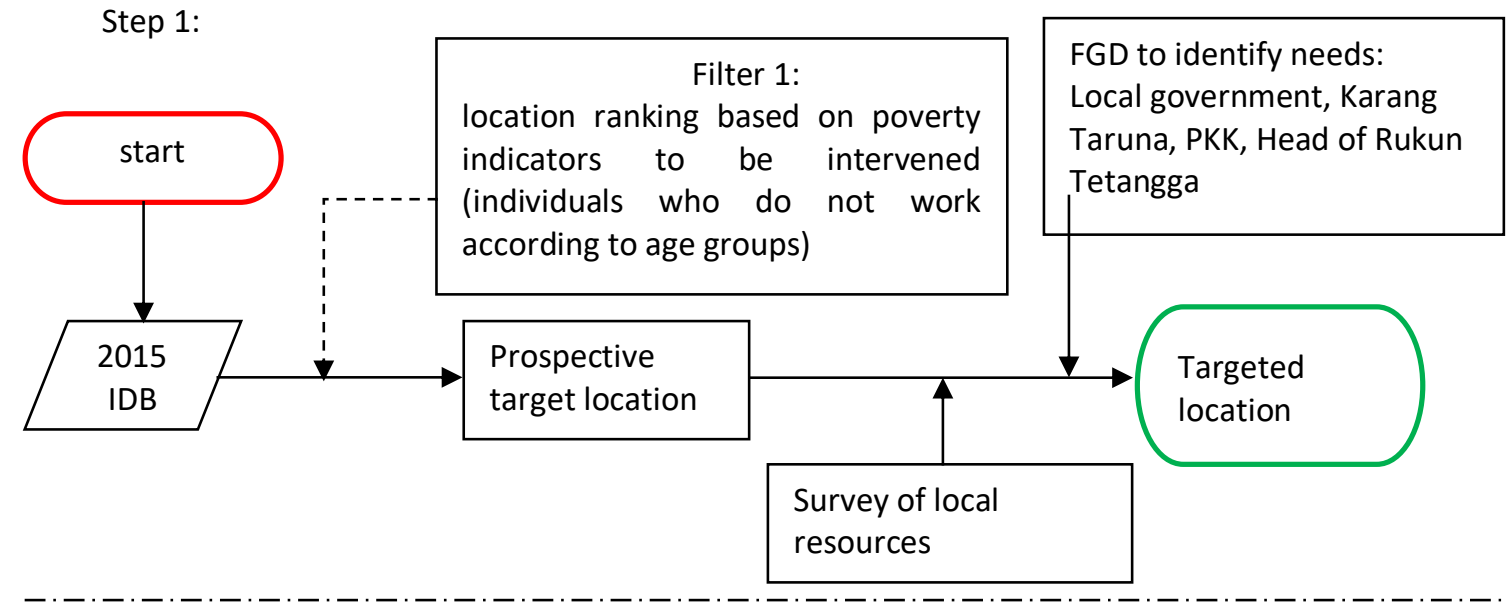

Step 2:

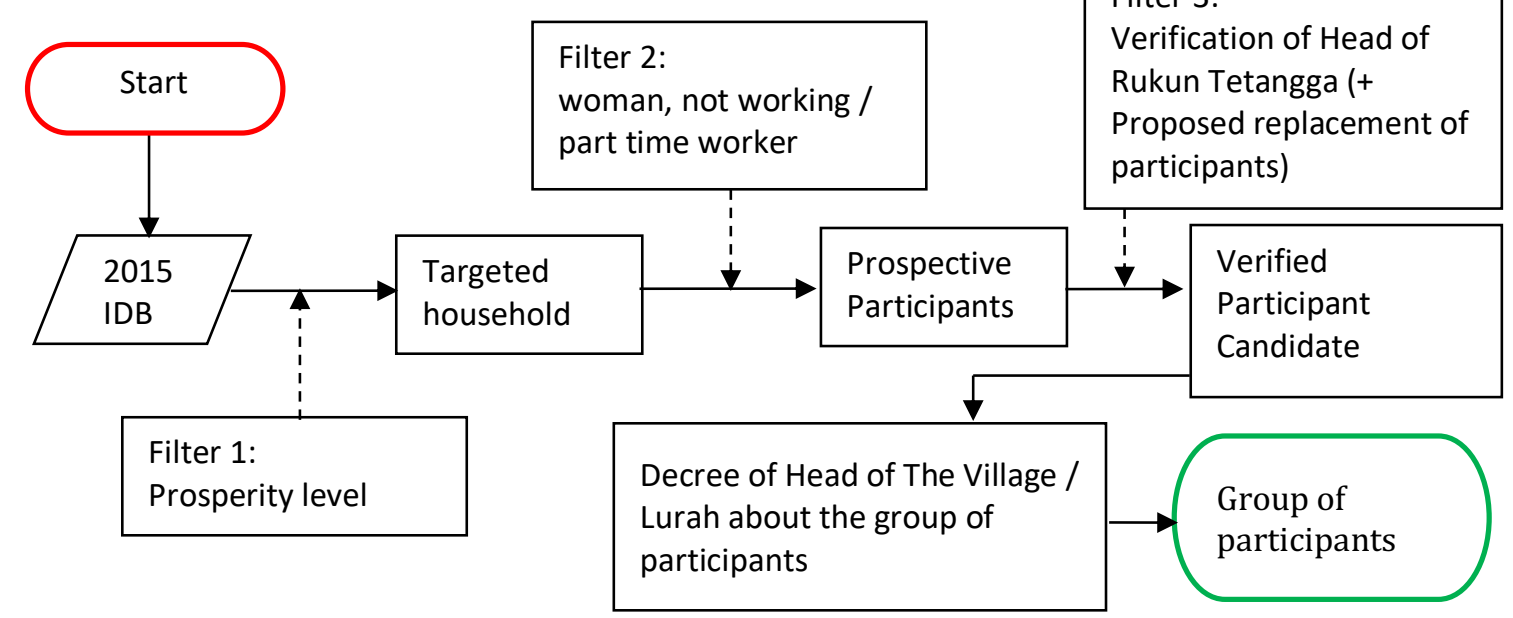

Figure 1 The Location and the participant determination processes

2. visiting the Head of the Neighborhood Association/HNA (Ketua Rukun Tetangga) to verify the prospective participants;

3. Forming the participant group through the decree of the Head of the Village/Lurah.

The informants involved in the study came from three groups:

1. Government Apparatus: Sub-district Head or its representative, the Head of the Village/Lurah or its representative, and the HNA;

2. Community organizations: Karang Taruna (a youth organization) and Kader Program Kesejahteraan Keluarga (the Family Welfare Program Cadre;

3. Business actors: Purun (Lepironia articulata) craftsmen and culinary business person.

The reliability of the 2015 IDB data as the source for selecting participants of a 
poverty alleviation program was tested using the test-retest reliability concept (Phelan \& Wren, 2006):

$$
\text { Reliability }(\%)=\frac{P_{i}}{P_{0}} x 100 \%
$$

where:

$\mathrm{P}_{0}$ : number of intended target participants listed in the 2015 IDB assumed eligible to include in community empowerment activities

$\mathrm{P}_{\mathrm{i}}$ : number of intended target participant listed in the 2015 IDB have found eligible to include in community empowerment activities

The measurement of the accuracy of the target program is carried out by comparing the Population Identification Number (PIN) of the intended target participants with the PIN of the actual participants:

$$
\text { Accuracy }(\%)=\frac{y}{x} \times 100 \%
$$

where:

$\mathrm{x}$ : number of intended target participants listed in the 2015 IDB

$\mathrm{y}$ : number of actual participant listed in the 2015 IDB

Identification of the participant needs carried out in two stages: the macro level that held at the sub-district level and the micro level at the neighborhood/household level. The identification of the participant needs at the macro level is carried out through the multi-stakeholders FGD whereas interviews are used for the micro level one. Sixteen keywords of community empowerment were used in this research: 1) altruism, 2) common value, 3) communal services, communications, 5) confidence, 6) context (political and administrative), 7) information, 8) intervention, 9) leadership, 10) networking, 11) organization, 12) political power, 13) skills, 14) trust, 15) unity and 16) wealth (Bartle, 2012). The conversation during FGD and interview noted in the field logbook. Every word related to or synonymously to research keywords resulted from the FGD and interview is highlighted. The keywords then analyzed by mapped in a causal relationship using the Theory of Change (Brest, 2010). The empowerment program then developed based on the participants needs.

\section{RESULTS AND DISCUSSION}

Reliability of the 2015 Integrated Data Base (IDB) usage and the Accuracy Level of Intended Target Participants Included in the Community Empowerment

One hundred and twenty-five of 256 individuals selected from the 2015 BDT as the intended target participants have found during a visit to the study site whereas the remaining could not meet due to the demographic dynamics (migration and mortality). Of these 125 individuals, eleven persons $(8.80 \%)$ were found not fulfilling the requirement to be included in the community empowerment activities. Therefore, the reliability score of the 2015 IDB data in this study was $91.20 \%$ estimated The findings showed that the 2015 IDB was relatively 
reliable as a reference for selecting the poverty alleviation program's targets at least to 2018 (though this conclusion is arguable yet the demographic dynamic naturally considered as uncontrolled factors that are fair enough to exclude from the reliability test).

The percentage of accuracy reached $44.53 \%$ in overall within the range of 14.29 -

Table 1 Summary of participants that listed in the 2015 IDB

\begin{tabular}{|c|c|c|c|c|c|}
\hline Kelurahan/Village & $\begin{array}{c}\text { Accuracy } \\
(\%)\end{array}$ & $\begin{array}{c}\text { age of } \\
\text { participant } \\
\text { (mean, years) }\end{array}$ & $\begin{array}{c}\text { Years of } \\
\text { Schooling of } \\
\text { Participant } \\
\text { (mean, years) }\end{array}$ & $\begin{array}{c}\text { Working hour in last } \\
\text { week before survey of } \\
\text { participant (mean, } \\
\text { hour)* }\end{array}$ & $\begin{array}{l}\text { indicated a positive } \\
\text { response to } \\
\text { empowerment } \\
\text { program** }\end{array}$ \\
\hline Tuan Kentang & 14.29 & 41.0 & 10.5 & 54.0 & Yes \\
\hline 2 Ulu & 22.22 & 39.5 & 7.5 & 0 & Yes \\
\hline Kemas Rindo & 23.81 & 38.0 & 6.2 & 60.0 & No \\
\hline Kertapati & 30.00 & 44.5 & 10.5 & 30.0 & Yes \\
\hline Silaberanti & 35.29 & 45.3 & 9.0 & 70.0 & No \\
\hline Menang Raya & 40.74 & 42.8 & 5.6 & 62.7 & Yes \\
\hline 5 Ulu & 43.48 & 38.0 & 9.2 & 65.0 & No \\
\hline Ogan Baru & 50.00 & 40.5 & 10.2 & 17.5 & No \\
\hline Kemang Agung & 50.00 & 37.6 & 9.7 & 24.0 & Yes \\
\hline Karya Jaya & 52.38 & 38.6 & 5.7 & 0 & No \\
\hline 3-4 Ulu & 53.85 & 39.6 & 6.4 & 0 & No \\
\hline Keramasan & 60.00 & 38.7 & 7.3 & 59.3 & No \\
\hline Pedamaran VI & 66.67 & 37.3 & 7.7 & 35.0 & Yes \\
\hline 9-10 Ulu & 73.68 & 36.8 & 8.9 & 37.7 & Yes \\
\hline Total & 44.53 & 39.9 & 7.8 & 48.9 & \\
\hline
\end{tabular}

Source: The 2015 IDB, TNP2K (prepared by authors)

* For the participant that economically active only

** The participant was continuing to develop the skill

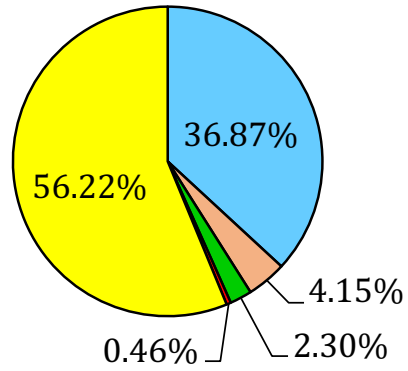

Decile1 Decile 2 Decile3

Palembang City

Ogan Komering Ilir Regency

Figure 2 Distribution of the participants based on categories of poverty deciles and research locations
$73.68 \%$ per Kelurahan/ Village. This accuracy level is considered relatively low that caused by the replacement of the intended target participants for the following reasons: moved to another village/kelurahan $(91.55 \%)$, already work $(4.22 \%)$, to have impaired health (3.52\%) and died (.70\%). 
The individual to replace the intended target participants proposed by the respective HNA tended not listed in the 2015 IDB. The unfamiliarity of the HNA to the 2015 IDB suspected as the cause (Rivani, 2016). There was only one of the HNA who knows about the 2015 IDB while the rest did not know because at the time of the 2015 IDB was collected were not yet in charge. The substitute known to has a personal relationship to the HNA, by kinship or sociopolitical preferences. No available information could be used for further analysis yet this phenomenon could be explained at least via the rational choice theory that individual preferences are self-interested (Scott, 2000). To increase the accuracy of the intended target participants included in community empowerment, stakeholders need to increase community awareness of the importance of data compiled by the government as a starting point (Bah et al., 2015).

\section{A. Community Empowerment Model}

The link and match of the macro and the micro level needs indicated the mutual needs shared by multi-stakeholders (Table 3). In general, these needs grouped into threefold: 1) access to product markets, 2) increase in production capacity and 3) a product quality improvement. The needs seemly corresponded to small-medium enterprises or small industries (SME's/SI) development.
Further exploration, based on the Potensi Desa 2014, the study's locations found to be SME's/SI center of webbing, woven or food processing (Table 2). Thus, the participant's needs to develop SME's/SI were considered relevant to the socioeconomic activity around them. Therefore, to empower them, handcrafting-skill that matched to the participant needs: woven (pincushion, coin purse, flower flannel-ornament), webbing (fashion purse from purun, necklace, brooch) or decoupage handcrafting were disseminated to each location and also gave initial working capital to stimulate small business growth.

Since our interest was to empower the participant listed in the 2015 IDB, the rest of this article would focus on them. For the background, we explored the human resources capital as summarized in Table 1. The participant completed the tertiary education/higher level found to be $1.61 \%$, the secondary was $45.16 \%$, the primary was $33.06 \%$ and the others were not completed/no school. Around $23 \%$ of participants (29 of 124) known economically active, but $20.7 \%$ of them were part-timer worker. Of the workers, $37.9 \%$ was self-employment, $31.0 \%$ was a labor/an employee, and the others were an agriculture freelance-worker or work to a family/unpaid worker.

The distribution of the participant response to the empowerment program based on selected characteristics showed in Table 4. 
The findings revealed that the working-hour of the participant, the level of education, the ratio of participant listed in the 2015 IDB, and handcrafting suitability to the local resource indicated a relation to the participant response. Part-time worker or low ratio of the participant listed in the 2015 IDB tended to give a more positive response to the empowerment program rather than its counterpart. On the other side, a relatively high educational level and the handcrafting suitability to the local resource found to give a more positive response compared to its counterpart. These findings were not backed up with statistical evidence, yet open to discussing.

Table 2. Distribution of small-medium enterprises or small industries unit

\begin{tabular}{lcccccc}
\hline Kelurahan/Village & $\begin{array}{c}\text { Wood } \\
\text { based }\end{array}$ & $\begin{array}{c}\text { Metal } \\
\text { based }\end{array}$ & $\begin{array}{c}\text { Webbing } \\
\text { based }\end{array}$ & $\begin{array}{c}\text { Earthenware } \\
\text { based }\end{array}$ & $\begin{array}{c}\text { Woven } \\
\text { based }\end{array}$ & $\begin{array}{c}\text { Food } \\
\text { processing }\end{array}$ \\
\hline Tuan Kentang & 1 & 0 & 0 & 0 & 15 & 2 \\
2 Ulu & 1 & 2 & 3 & 0 & 2 & 10 \\
Kemas Rindo & 0 & 0 & 1 & 0 & 0 & 0 \\
Kertapati & 0 & 0 & 0 & 0 & 0 & 0 \\
Silaberanti & 1 & 0 & 0 & 0 & 1 & 20 \\
Menang Raya & 1 & 0 & 960 & 0 & 0 & 2 \\
5 Ulu & 3 & 1 & 0 & 2 & 2 & 5 \\
Ogan Baru & 1 & 0 & 0 & 4 & 60 & 0 \\
Kemang Agung & 0 & 0 & 1 & 0 & 3 & 0 \\
Karya Jaya & 0 & 0 & 0 & 0 & 0 & 1 \\
3-4 Ulu & 0 & 0 & 32 & 0 & 10 & 20 \\
Keramasan & 3 & 0 & 1 & 0 & 10 & 4 \\
Pedamaran VI & 1 & 0 & 200 & 3 & 0 & 0 \\
9-10 Ulu & 1 & 0 & 0 & 0 & 0 & 150 \\
\hline \multicolumn{1}{c}{ Total } & & & & & & \\
\hline
\end{tabular}

Table 3 Summary of the needs identification based on research location and level

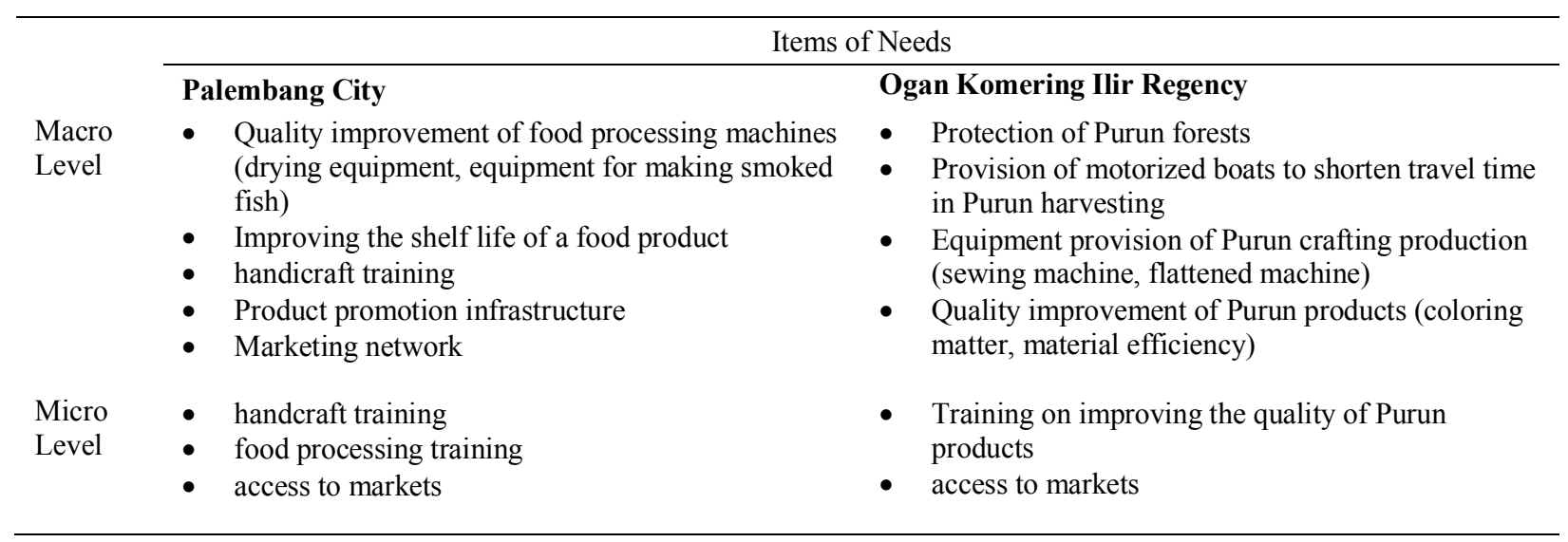


Table 4 Distribution of the participant response to empowerment program

\begin{tabular}{lcccccccc}
\hline \multirow{2}{*}{$\begin{array}{l}\text { Responses to } \\
\text { empowerment } \\
\text { program }\end{array}$} & \multicolumn{2}{c}{ Working hour (\%) } & \multicolumn{2}{c}{ Level of education (\%) } & $\begin{array}{c}\text { Ratio of participant } \\
\text { listed in the 2015 } \\
\text { IDB in the group (\%) }\end{array}$ & $\begin{array}{c}\text { Handcrafting } \\
\text { suitability to local } \\
\text { resources (\%) }\end{array}$ \\
\cline { 2 - 10 } & $\begin{array}{l}\text { part-time } \\
\text { worker }\end{array}$ & $\begin{array}{c}\text { full-time } \\
\text { worker }\end{array}$ & $\begin{array}{c}\text { no school or } \\
\text { elementary }\end{array}$ & $\begin{array}{c}\text { high school } \\
\text { or higher }\end{array}$ & low & high & No & Yes \\
\hline Negative response & 42.9 & 57.1 & 57.1 & 42.9 & 40.0 & 55.6 & 62.5 & 33.3 \\
Positive response & 57.1 & 42.9 & 42.9 & 57.1 & 60.0 & 44.4 & 37.5 & 66.7 \\
Total & 100 & 100 & 100 & 100 & 100 & 100 & 100 & 100 \\
\hline
\end{tabular}

Table 5 Distribution of the participant that gave a positive response

\begin{tabular}{|c|c|c|c|}
\hline \multirow{2}{*}{ Indicator } & & \multicolumn{2}{|c|}{ Education level (\%) } \\
\hline & & High & Low \\
\hline \multirow{2}{*}{ the participant's working hour } & Part-time worker & 50.0 & 33.3 \\
\hline & Full-time worker & 50.0 & 66.7 \\
\hline \multirow{2}{*}{$\begin{array}{l}\text { ratio of the participant listed in the } 2015 \text { IDB in the } \\
\text { group }\end{array}$} & Low-ratio & 50.0 & 33.3 \\
\hline & High-ratio & 50.0 & 66.7 \\
\hline \multirow{2}{*}{ handcrafting suitability to a local resources } & Not matched & 50.0 & 0.0 \\
\hline & Matched & 50.0 & 100.0 \\
\hline
\end{tabular}

Of the participant that gave a positive response, a full-time worker with lesser education level tended to accept the empowerment program rather than its counterpart. A similar result also found for categories of the ratio of the participant listed in the 2015 IDB and the handcrafting suitability to a local resource (Table 5). The empirical findings revealed two paths of persuasion as described in the Elaboration Likelihood Model. On the participant with a better education level, a cognitive process presumed as the main factor to accept the empowerment program. Nevertheless, the effect of a cognitive process seems reduced if another factor were included in the analysis. The findings suggest that the participant with different education level had an equal chance to accept empowerment program. The study also revealed an influence of the community's leader as an important factor in the empowerment program. Two of fourteen community's leader here were Kepala Desa (head of the village) which is a leader that chosen by election whereas the others were Lurah (civil servant). These two of community's leader were acted as the facilitator to the participant while its counterpart relatively focused on administrative work (and that was not good in our case). These findings were inlined to Cho, Hwang, and Lee (2012) findings that opinion leader with high sociality are the best ones for fast diffusion.

The additional problems should be concern probably how to maximize the acceptance of the empowerment program 
across a different group. The empowerment program itself delivered through learning-bydoing method guided by professional at their home. The method was believed to boost the self-efficacy of the participant to modify her knowledge to solve their own problems (Anders, 2018), to garner customers and to deliver the product or service which an important step in establishing a small business development (Machin, Adkins, Crosby, Farrell, \& Mirabito, 2018). Although every Decile had significant household's asset differences, the findings showed the asset was not given different influence to the responsiveness of the participant to the empowerment program. Therefore, the poverty alleviation program that only targeted poverty enclaves were not too right in these case. The findings also revealed that rather than only to focus on individual capacity development, the empowerment program would be more effective if the community's asset were also developed (Cassidy \& Jakes, n.d.).

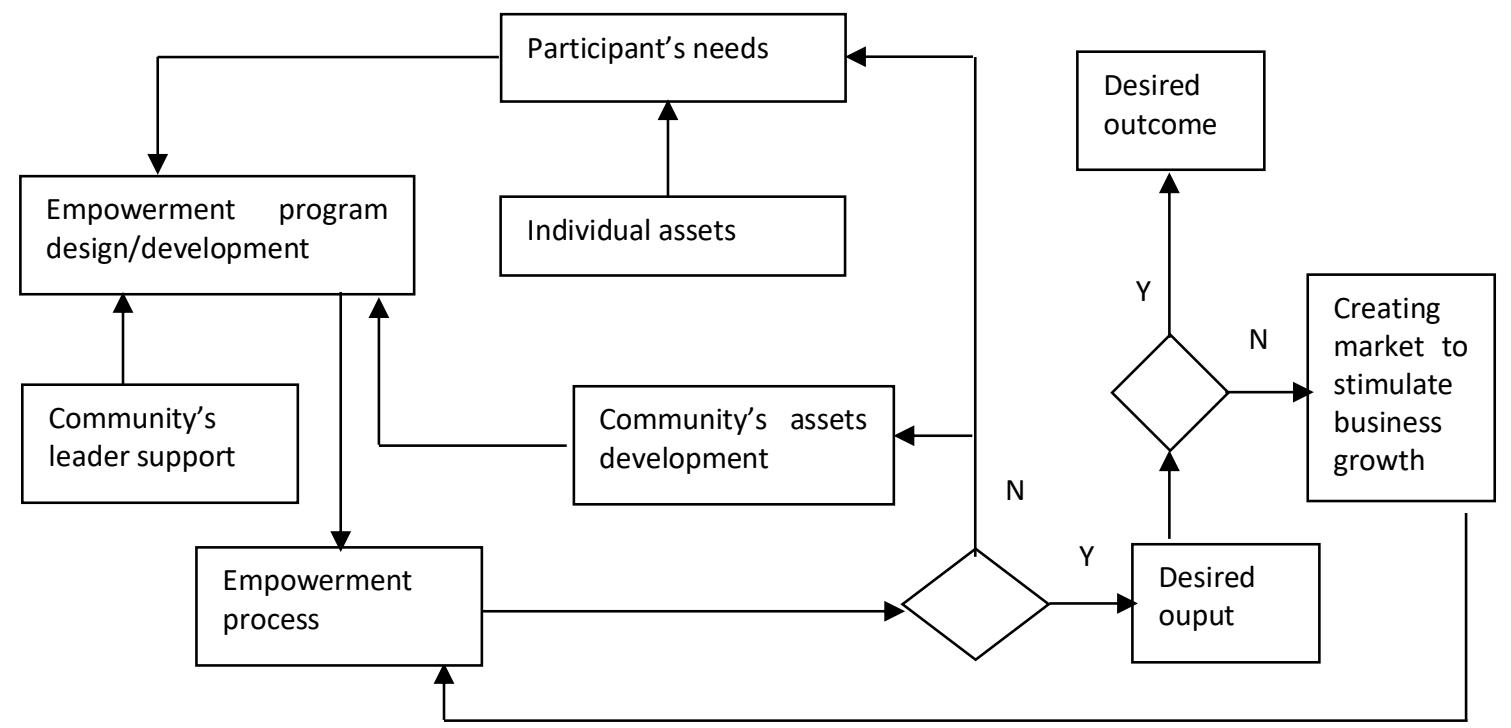

Figure 3 Proposed empowerment model

All of the locations where the participant has shown positive responses known had its own local 'trademark'. For example, Pedamaran Sub-district - the administrative area where is Menang Raya and Pedamaran VI villages are - is famous as Purun mat producer. The participant certainly gave a positive response to handcrafting skill related to Purun that being disseminated to them. But the problem is if the participant will use the acquired skill to change the way of their business? There is always doubt if their 'new' Purun product - in this case was a fashion bag - is marketable. At this point, the immediate response of the Head of Menang Raya Village to reduce the doubt was by building a showroom to promote the new product although this action did not directly make their product absorbed 
by a market. But, the building gave an optimistic feel that what they did is supported, and consequently motivated the participant to apply the acquired skill. The Head of Menang Raya Village also facilitated initial working capital for the participant to fulfill the first order of the new product around 200 unit goody-bag. For the short term, these actions seemed effective because fulfilling two of basic needs in business development which were business promotion and customer garner.

\section{CONCLUSION}

The reliability of the 2015 IDB as the source in selecting of the community empowerment participant was depended on the ability of program manager in diminishing of identity politics at the location. Since the IDB always be updated biennially, it will remain reliable as long as 'individual's fact findings' conducted properly. In account to increase the responsiveness of the participant to the empowerment program, the community's assets also need to be developed alongside individual assets. The empowerment program is indeed an iterative process rather than linear, the program manager should aware of constant changing of the participant needs.

\section{RECOMMENDATION}

The study recommends to local governments to improve the ability of village head entrepreneurs as an entry point in diffusing an innovation to the communities they lead. The local governments should create an initial market to ensure continuity of an innovative product since small and medium enterprises have limited capital cash flow.

\section{ACKNOWLEDGEMENT}

The authors thank Oom Komalasari and Wenni Tania Defriyanti for assisted during data collection and conceptual development. The authors also thank anonymous reviewers for insightful comments in the manuscript preparation.

\section{REFERENCES}

Anders, A. D. (2018). Networked learning with professionals boosts students' self-efficacy for social networking and professional development. Computers \& Education, 127, 13-29.

https://doi.org/10.1016/j.compedu.2018.08. 009

Bah, A., Nazara, S., \& Satriawan, E. (2015). Basis Data Terpadu di Indonesia untuk Program Perlindungan Sosial. International Policy Centre for Inclusive Growth, (49).

Bartle, P. (2012). Elements of Community Strength. Retrieved from http://cec.ven.bc.ca/cmp/modules/meaele.htm

Brest, P. (2010). The Power of Theories of Change. Retrieved from Stanford Social Innovation Review website: $\mathrm{https} / / / \mathrm{ssir}$. org/articles/entry/the power of theories of change

Cassidy, L., \& Jakes, S. (n.d.). Citizen Development: A Brief Review of the Literature. Retrieved from Evaluating the National Outcomes website: https://cals.arizona.edu/sfcs/cyfernet/nowg/ 
cd_litrev.html

Cho, Y.., Hwang, J., \& Lee, D. (2012). Identification of effective opinion leaders in the diffusion of technological innovation: A social network approach. Technological Forecasting and Social Change, 79(1), 97106.

https://doi.org/10.1016/j.techfore.2011.06. 003

Costa, G. O. T., Machado, A. F., \& Amaral, P. V. (2017). Vulnerability to poverty in Brazilian municipalities in 2000 and 2010: A multidimensional approach. EconomiA. https://doi.org/10.1016/j.econ.2017.11.001

Fiszbein, A., Kanbur, R., \& Yemtsov, R. (2014). Social Protection and Poverty Reduction: Global Patterns and Some Targets. World Development, 61, 167-177. https://doi.org/10.1016/j.worlddev.2014.04 .010

Haughton, J., \& Khandker, S. R. (2009). Handbook on Poverty and Inequality. Washington, DC, DC: The World Bank.

Liu, Q. Q., Yu, M., \& Wang, X. L. (2015). Poverty reduction within the framework of SDGs and Post-2015 Development Agenda. Advances in Climate Change Research, 6(1), 67-73. https://doi.org/10.1016/j.accre.2015.09.004

Machin, J. E., Adkins, N. R., Crosby, E., Farrell, J. R., \& Mirabito, A. M. (2018). The marketplace, mental well-being, and me: Exploring self-efficacy, self-esteem, and self-compassion in consumer coping. Journal of Business Research. https://doi.org/10.1016/j.jbusres.2018.12.0 28

Mellor, J. W., \& Malik, S. J. (2017). The Impact of Growth in Small Commercial Farm Productivity on Rural Poverty Reduction. World Development, 91, 1-10. https://doi.org/10.1016/j.worlddev.2016.09 .004

Phelan, C., \& Wren, J. (2006). Exploring Reliability in Academic Assessment. Retrieved from https://chfasoa.uni.edu/reliabilityandvalidit y.htm

Rivani, E. (2016). Peran Sumber Data Tunggal Dalam Mendukung Ketepatan Sasaran Program Percepatan Penanggulangan Kemiskinan. Kajian, 21(2).

Scott, J. (2000). Rational Choice Theory. In G. Browning, A. Halcli, \& F. Webster (Eds.), Understanding Contemporary Society: Theories of The Present. Retrieved from https://web.archive.org/web/200902270850 05/http://privatewww.essex.ac.uk/ scottj/s ocscot $7 . h$ tm

Sekretariat TNP2K, \& TNP2K, S. (2012). Tanya Jawab 2012. Jakarta: Tim Nasional Percepatan Penanggulangan Kemiskinan.

Sitepu, A. (2015). Implementasi Kebijakan Program Subsidi Beras Untuk Masyarakat Berpenghasilan Rendah di Provinsi Nusa Tenggara Barat. Sosio Konsepsia, 4(2).

Sudibyo, E. (2019). Strategi Pemerintah Dalam Akurasi Pendataan Kemiskinan. Karta Raharja, 1(1).

TNP2K. (n.d.). Sekilas Strategi Percepatan. Retrieved from http://www.tnp2k.go.id/id/kebijakanpercepatan/strategi-percepatanpenangulangan-kemiskinan/sekilasstrategi-percepatan/

Vinda, K. (2017). Efektivitas Program Pemberdayaan Masyarakat Dalam Kelompok Usaha Bersama (Studi Kasus Pada Pemberian Bantuan Mesin Jahit Kelompok Usaha Bersama Bunga Sejahtera Desa Ngampungan Kecamatan Bareng Kabupaten Jombang). Publika, 5(1). 